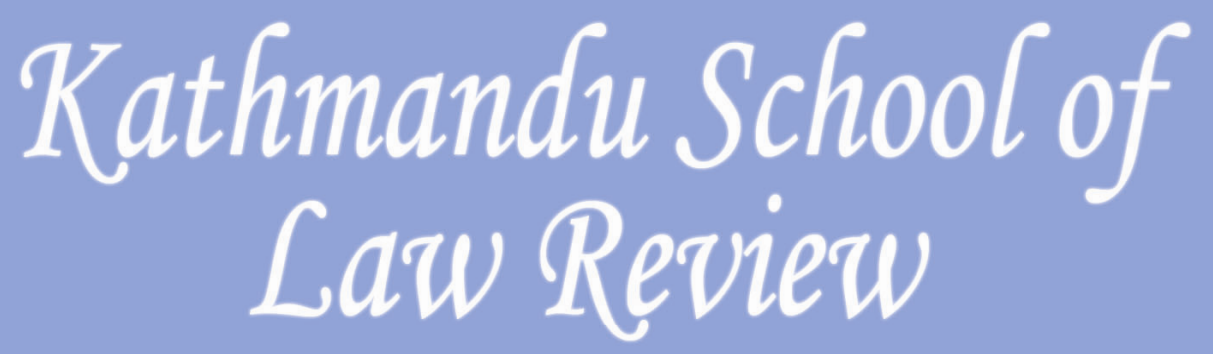

ISSN 2091-2110

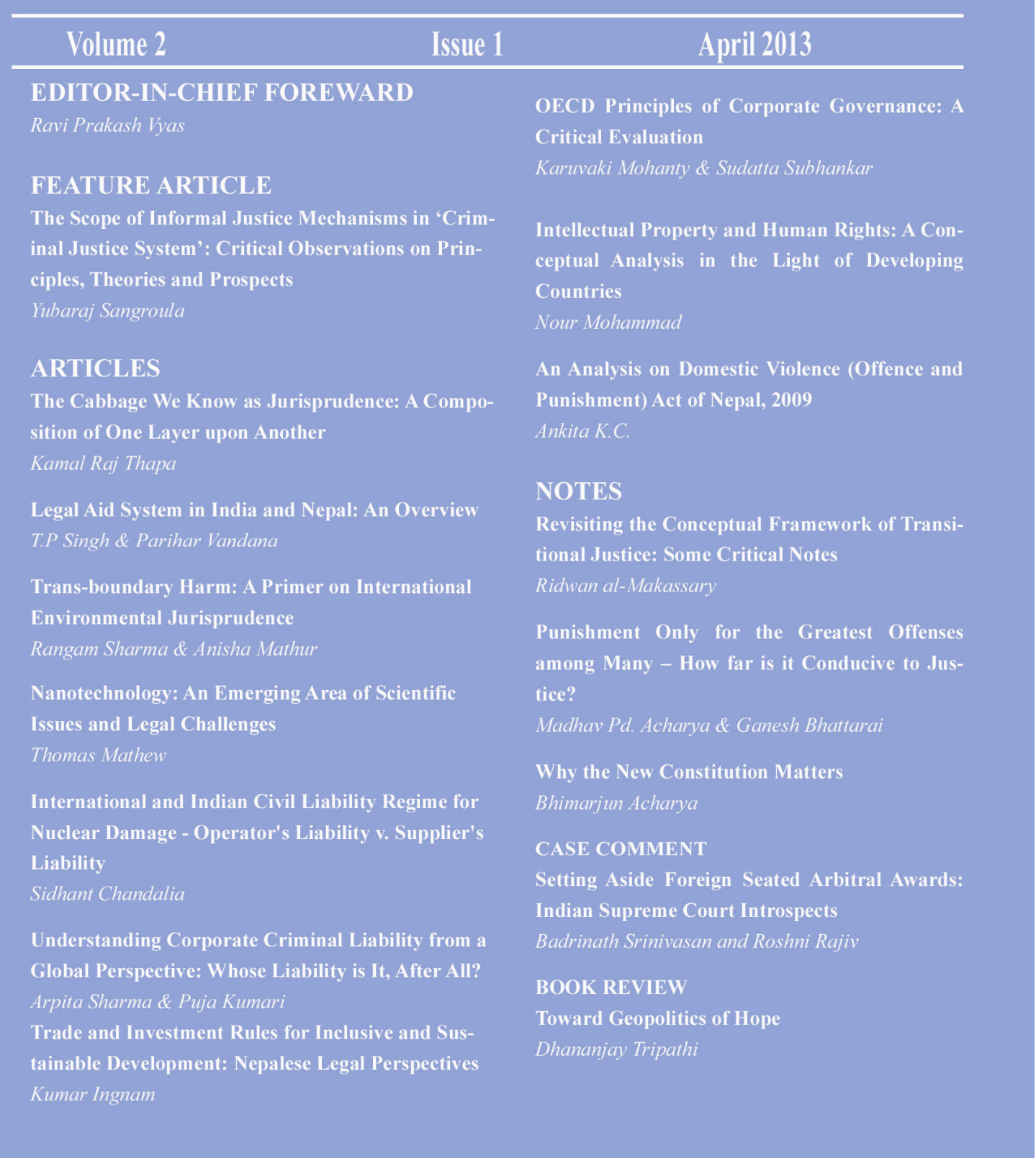




\title{
Intellectual Property and Human Rights: A Conceptual Analysis in the Light of Developing Countries
}

\author{
Nour Mohammad ${ }^{1}$
}

\begin{abstract}
This paper examines some competing legal frameworks that governments, $N G O s$, and intergovernmental organizations are using to conceptualize the intersection of human rights and intellectual property. Among the two approaches examined, the first approach views the two areas of law as in fundamental conflict, with strong intellectual property protection standards in particular those of the TRIPS Agreement undermining a broad spectrum of human rights. The second approach sees both areas of law as concerned with the same basic question. This paper aims to critically analyze different provisions of the intellectual property and to search for the implications of them for the developing countries in line with the Human right. Finally an attempt is made to explore ways and means in mitigating or addressing the problems arising out of the TRIPS which are peculiar to the developing countries
\end{abstract}

\section{Introduction}

Human rights and intellectual property rights are to a large extent, fields of law that have evolved separately. Intellectual property rights consist of statutorily recognized rights, which provide incentive for the participation of the private sector in certain fields and seek to contribute to technological development. Human rights are fundamental. They are recognized by the state but are inherent rights linked to human dignity. Bangladesh being a developing country, has intellectual property laws which are not improved and modern. So, improvement in this kind of law simultaneously with the development of the state and insurance of human rights and dignity is essential. ${ }^{2}$

Assistant Professor of Law, Premier University Chittagong, Bangladesh

Cullet Philippe, 'Human Rights and Intellectual Property protection in the TRIPS Era' (2007) 29 Human Rights Quarterly 403. 
The connection between intellectual property rights and human rights has been acknowledged for many decades. It is recognized in the field of science and technology, related provisions of the Universal Declaration of Human Rights ${ }^{3}$ and in other international and regional human rights treaties and instruments. The approaches are adopted in established intellectual property law making organizations, such as the WTO and WIPO. The new human rights approach to intellectual property is often critical of existing standards of protection and it seeks to address legal and policy issues that intellectual property treaty makers and legislators often ignore.

However, the relationship between intellectual property law and human rights is very complex and difficult and calls for a full understanding of the nature and purposes of the intellectual property law system. It is suggested by some author that conflicts may exist between the respect for and implementation of current intellectual property law systems and other human rights, such as the rights to adequate health care, right to education, right to share in the benefits of scientific progress, and right to participation in cultural life along with others.

\section{The TRIPS Agreement and Human Rights}

The area of intersection between intellectual property and human rights relates to the TRIPS Agreement adopted in 1994 as part of the World Trade Organization (WTO) ${ }^{4}$. The World Trade Organization is an international organization that aims to promote trade and economic development through the reduction of tariffs and trade barriers. ${ }^{5}$ The TRIPS agreement is based on the Paris, Berne, Rome and Washington conventions in their respective fields along with additional mandatory obligations. The TRIPS agreement is a minimum standards agreement. It places no obstacles in the way of countries which may wish to provide a higher level of protection of intellectual property; indeed it explicitly permits them to do so. For that reason, the TRIPS agreement has been called the most ambitious international intellectual property convention ever attempted. The United Nation Human Rights system focused its attention to TRIPS agreement in 2000, just when the treaty's transitional periods were expiring for developing countries ${ }^{6}$. In the same year the Sub-Commission on the Promotion and Protection of Human Rights adopted Resolution 2000/7 on Intellectual Property Rights and Human Rights. ${ }^{7}$ The resolution adopts an antagonistic approach towards TRIPS.

Universal Declaration of Human Rights (adopted 10 December 1948) UNGA Res 217A (III).

Agreement on Trade-Related Aspect of Intellectual Property Rights (15 April 1994) 1869 UNTS. 299,

33 ILM 1197 (TRIPS); Marrakesh Agreement Establishing the World Trade Organization (1994) 1867 UNTS 154, 33 ILM 1144 (Marrakesh Agreement).

5 Marrakesh Agreement (n 4), preamble.

6 See (For a review of the changes TRIPS brought) J H Reichman, The TRIPS Agreement comes of age: Conflict or cooperation with developing countries (2000).

7 See David Weissbrodt \& Kell Schoff, 'A Human Rights Approach to Intellectual Property Protection: The Genesis and Application of Sub-commission Resolution 2000/7' (2003) 5 Minn Inte Prop Rev 1. 
Every member states of the TRIPS agreement have an obligation to establish a minimum level of protection for intellectual property rights. The TRIPS agreement provides certain clear benchmarks for such protection, while leaving many significant issues open. It is however clear from the TRIPS agreement that countries must provide patents for medicines. Accordingly, Article 27 (1) provides that:

Subject to the provisions of para 2 and 3, patent shall be available for any inventions, whether products or processors, in all fields of technology, provided that they are new, involve an inventive step and are capable of industrial application ${ }^{8}$ Subject to paragraph 4 of Article 65,para 8 of Article 70 and para 3 of this same Article, patent shall be available and patent rights enjoyable without discrimination as to the place of invention ,the field of technology and whether products are imported or locally produced.

Article 7(1) of the TRIPS agreement provides that an overarching principle of the Agreement is the protection of public health and the promotion of public interests:

Members may, in formulating or amending their laws and regulations, adopt measures necessary to protect public health and nutrition, and to promote the public interest in sectors of vital importance to their socio-economic and technological development, provided that such measures are consistent with the provisions of this Agreement.

The TRIPS agreement furthermore allows member states to exclude from patentability of certain products and processes as 'Members may exclude from patentability inventions, the prevention within their territory of the commercial exploitation of which is necessary to protect ordre public or morality, including to protect human, animal or plant life or health or to avoid serious prejudice to the environment, provided that such exclusion is not made merely because the exploitation is prohibited by their law. ${ }^{9}$

\section{The Concept of TRIPS Agreement}

The importance of framing some sort of an internationally recognized agreement for cooperation among nations for the protection of intellectual property was recognized as early as in the year 1883 when Paris Convention for protection of industrial property came into existence. The said Paris Convention for protection of industrial property was a landmark international event when as many as 140 states signed the convention and agreed to implement its provisions. The Convention used the term 'industrial property' in the widest sense. Article1(2) of the convention states that 'the protection of industrial property has its

\footnotetext{
8 For the purposes of this Article, the terms 'inventive step' and capable of industrial application may be deemed by a member to be synonymous with terms 'non-obvious' and 'useful' respectively.

$9 \quad$ TRIPS (n 4) art 27(2).
} 
object patents, utility models, industrial design, trade mark, service mark trade names indication of source or appellations of origin and the repression of unfair competition' ${ }^{10}$

One of the remarkable features of the Paris Convention was the concept of a 'Union' meaning that the countries to which that convention applied constituted a union for the protection of industrial protection of industrial property. This meant that a national of any country of the union as regards the protection of industrial property enjoyed in all other countries of the union the advantages that its respective laws granted to its own nationals. The TRIPS agreement has adopted this provision of the Paris Convention- the national of a signatory country would have equivalent rights and status in all other signatory countries. ${ }^{11}$

\section{Analysis of TRIPS agreement in Light of Human Rights Obligations}

Human rights are linked with the work of the WTO in many different ways. Human rights operate as an external legal framework which creates obligations for governments in the implementation of WTO Agreement. Most of the member states of WTO have ratified various human rights treaties, such as The International Covenant on Economic Social and cultural rights, 1966 (ICESCR) and CEDAW. These human rights treaties are like WTO Agreements, and are legally binding among the states who are member of the WTO. Governments must respect, protect and fulfil human rights obligations in all their undertakings, including in the area of international trade. The Committee on Economic, Social and Cultural Rights (CESCR), which monitors the implementation of ICESCR, has confirmed this principle in its country reports. According to the CESCR, "obligations under ICESCR should be taken into account in all negotiations with international financial institutions, such as International Monetary Fund, World Bank and WTO, to ensure that economic, social and cultural rights are not undermined."12 In its Resolution 2000/7, the UN Sub-Commission on the Promotion and Protection of Human Rights reminded governments of the "primacy of human rights obligations over economic policies and agreements. ${ }^{13}$ Similarly, the UN High Commissioner for Human Rights has recommended that 'Members should...implement the minimum standards of the TRIPS Agreement bearing in mind both their human rights obligations as well as the flexibility inherent in the TRIPS Agreement, and recognizing that human rights are the first responsibility of Governments'. ${ }^{14}$

$10 \quad$ Ibid s 1.

11 Carlos M. Correa \& Abdulqawi A. Yusuf (eds), Intellectual Property and International Trade: The Trips Agreement ( Kluwer Law Internatinal 1998) 215.

12 See, for example, CESCR, Consideration of reports submitted by states parties under articles 16 and 17 of the covenant: Algeria E/C.12/1/ADD.71 (30 November 2001) para 43.

13 Intellectual Property Rights and Human Rights, Sub-Commission on Human Rights Resolution 2000/7 (17 August 2000) E/CN.4/SUB.2/RES/2000/7 para 3.

14 The Impact of the Agreement on Trade-Related Aspects of Intellectual Property Rights on Human Rights: Report of the High Commissioner (27 June 2001) E/CN.4/Sub.2/2001/13, para 60. 
It may be argued that human rights govern or at least should govern the interpretation of WTO rules by relevant WTO bodies. Under this argument, WTO Dispute Settlement Panels and the Appellate Body should apply human rights norms in their decisions and WTO member states should be able to refer to human rights commitments when determining their obligations under the WTO Agreements. ${ }^{15}$ For instance, a Member State should be able to cite the promotion of the right to health as a reason for allowing parallel importation of generic drugs. However, WTO Agreements do not refer to human rights instruments. While WTO Agreements allow for exceptions to the rules if this is necessary to protect the ordre public and morality, they do not link these concepts to human rights or human rights instruments. Moreover, neither WTO Dispute Settlement Panels nor the Appellate Body has referred to human rights in their decisions.

Trade and human rights can be seen in balancing terms. Intellectual property rights are human rights as well; as such, they both support and are balanced by social, economic and cultural rights, including the right to health. Article 27(2) of the Universal Declaration of Human Rights stated that: 'Everyone has the right to the protection of the moral and material interests resulting from any scientific, literary or artistic production of which he is the author.

Human rights, intellectual property, TRIPS and multilateral trade agreements are all part of the same international legal system. Although human rights obligations are not unequivocal in the TRIPS Agreement, they bind the governments in their all activities, including those related to implementing TRIPS. UN human rights bodies monitor patent regulation as part of the implementation review of human rights treaties.

\section{Implications of the TRIPS agreement on Developing Countries}

Bangladesh, being a member of WTO, has to implement the TRIPS agreement in totality. While the Laws on Trademark, Copyright and Design are almost in conformity with the provision of the TRIPS agreement, the patent laws are a cause of concern. But in 2009, the new Trademark law was passed replacing the old one in compliance with the TRIPS agreement.

Bangladesh is a social welfare state. Bangladesh did not begin to grant patent protection for pharmaceutical products until 2002. But India has amended its patent law to include product patent in pharmaceutical industry. Bangladeshi industry has to necessarily engage itself in new product development to remain globally competitive. Evidently none of the Bangladeshi companies have the financial strength to undertake drug development as a part of its research and development portfolio. The Government is already burdened with its own compulsions. Government financial support to research and development wings of pharmaceutical industry does not seem to be a probability. ${ }^{16}$

\footnotetext{
15 See, for example, Ernst-Ulrich Petersman, 'The WTO Constitution and Human Rights' (2000) 3 Journal of International Economic Law 10.

16 Ibid 10.
} 
In agricultural sector the farmers would be burdened by obligation of paying royalties to the suppliers of improved variety of seeds who would be the patent owners for such seeds. Thus there would both be scarcity of food-grain which would further aggravate the already bad position and could add fuel to fire. Our populations dependent on agriculture for their livelihood have become poorer and more under nourished and per capita availability of food grains has also declined which is a major concern for us. Invoking the provision of Compulsory Licensing on the ground of non-availability of the patented invention to the public at reasonable prices would not be easily possible once ${ }^{17}$ The Bangladeshi Patent Act is brought in accordance with the provision of TRIPS agreement

The traditional knowledge of medicine in Bangladesh, Unani Ayurvedic is also threatened by system of product patent. The medicinal products have existed in the country for centuries without anyone exercising a monopoly right over them. In a post-TRIPS scenario if a person gets patent for such a product abroad, he would be entitled to an exclusive right in the product. This implies that citizens of Bangladesh would have to pay the price fixed by the patentee since the owner would have the monopoly right to determine the price and supply of such product. The Bangladeshi people would lose what has been theirs for centuries. The answer lies in enacting suitable legislation to protect our heritage ${ }^{18}$

The first group comprises those countries which already have legislation that conforms to a considerable degree with the substantive standard of the TRIPS agreement. Some of these countries have introduced significant changes in their intellectual property rights legislation in the last five to ten years as a result of pressure and threats by the USA to apply section 301 of the US Trade Act. In these countries, the level of substantive adjustment required may not be very significant, though changes in certain aspects or the enactment of new legislation (e.g. concerning layout design of integrated circuits) may be necessary to satisfy the Agreement's provision. In particular this may apply to the provision relating to the enforcement of intellectual property rights, ie, those that regulate the judicial and administrative actions available to private parties to combat infringement of intellectual property right 19

A second group consists of countries that, despite foreign pressure, have not yet amended their legislation or have done so partially. In this case, legislation action will be required and the implication will be wide-reaching and significant. They will, however, differ sector by sector. A comprehensive analysis of the implication of the TRIPS agreement for developing countries is however, beyond the scope of this document. When drafting the legislation or considering its eventual review, developing counties should take account of

17 Charles S. Levy, 'Law and Policy in International Business' Review of key substantive Agreement' (2000) 31 Law \& Pol'y Int'l Bus 789.

$18 \quad$ Ibid 801.

19 Rapheal Kaplinsky, 'Industry and intellectual property rights in the Uruguay round and beyond' (1989) 25 (3) The Journal of Development Studies. 
the possible impact of the new framework for intellectual property rights on local innovation, technology transfers, foreign direct investment and trade. No conclusive evidence exists on the benefits and costs of reinforcing intellectual property rights. They are likely to vary considerable in accordance with the level of economic and technological development of the country concerned. Some of the key aspects to be addressed have been outlined below. ${ }^{20}$

\section{Human Rights and Intellectual Property: Conflict and Co-Existence}

After the establishment of the World Trade Organization (WTO) and the entering into effect of the Agreement on Trade-Related Aspects of Intellectual Property Rights ${ }^{21}$ (TRIPS agreement), government officials, international bureaucrats, intergovernmental and nongovernmental organizations, courts, and scholars have focused considerable attention on the interplay of intellectual property and human rights. In recent years, some scholars have begun to advocate the development of a comprehensive and coherent human rights framework for intellectual property law and policy ${ }^{22}$.Such a framework would not only be socially and economically beneficial, but would also enable countries to develop a balanced intellectual property system that takes into consideration their international human rights obligations. ${ }^{23}$ To better understand the interplay of intellectual property and human rights, and how such a framework can be developed, the Committee on Economic, Social and Cultural Rights (CESCR) recently provided an authoritative interpretation of article 15(1)(c) of the International Covenant on Economic, Social and Cultural Rights (ICESCR) ${ }^{24}$ in General Comment No. $17 .{ }^{25}$ From the very beginning, the Committee differentiates the right to the protection of interests in intellectual creations of the creators from most legal entitlements recognized in intellectual property systems. ${ }^{26}$ As the Committee elaborated: Human rights are fundamental as they are inherent to the human person as such, whereas intellectual property rights are first and foremost means by which States seek to provide incentives for inventiveness and creativity, encourage the dissemination of creative and innovative

20 Lisa B.Martin \& Susan L. Amster, International Intellectual Property Protection in the New GATT Accord' (1993) 2 J. Proprietary Rts. 9, 12.

21 TRIPS (n 4).

22 L.R. Helfer, 'Toward a Human Rights Framework for Intellectual Property' (2007) 40 U.C. Davis Law Review 977; P.K.Yu, 'Reconceptualizing Intellectual Property Interests in a Human Rights Framework' (2007) 40 UC Davis Law Review 1039.

23 P.K. Yu (n 22) 1123.

24 International Covenant on Economic, Social and Cultural Rights (adopted 16 December 1966) 993 UNTS 3 art 15(1)(c).

25 Committee on Economic, Social and Cultural Rights, General Comment No. 17: The Right of Everyone to Benefit from the Protection of the Moral and Material Interests Resulting from Any Scientific, Literary or Artistic Production of Which He Is the Author (Art. 15(1) (c)), para. 35 (12 January 2006 ) UN Doc. E/C.12/GC/17.

26 Ibid para 1. 
productions, as well as the development of cultural identities, and preserve the integrity of scientific, literary and artistic productions for the benefit of society as a whole.

In contrast to human rights, intellectual property rights are generally of a temporary nature, and can be revoked, licensed or assigned to someone else. While under most intellectual property systems, intellectual property rights, often with the exception of moral rights, may be allocated, limited in time and scope, traded, amended and even forfeited whereas, human rights are timeless expressions of fundamental entitlements of the human person. The human right to benefit from the protection of the moral and material interests resulting from one's scientific, literary and artistic productions safeguards the personal link between authors and their creations and between peoples, communities, or other groups and their collective cultural heritage, as well as their basic material interests which are necessary to enable authors to enjoy an adequate standard of living, intellectual property regimes primarily protect business and corporate interests and investments. Moreover, the scope of protection of the moral and material interests of the author provided for by article 15, Para 1(c), does not necessarily coincide with what is referred to as intellectual property rights under national legislation or international agreements. ${ }^{27}$ To highlight the distinction and avoid confusion between the right protected in article 15(1)(c) and the so-called intellectual property rights, a catch-all term that is used to describe copyrights, patents, trademarks, trade secrets, and other existing and newly-created related rights. The terms the right to the protection of moral and material interests in intellectual creations 'or, its shorter form, the right to the protection of interests in intellectual creation's are used here. Although these terms seem long and clumsy, they are superior to their shorthand counterparts, as those titles tend to obscure the real meaning of the obligations that these rights impose $\mathrm{e}^{28}$.

While the development of a human rights framework for intellectual property is important, sceptics have expressed concern over the danger of an arranged marriage between intellectual property and human rights. Their scepticism is not new. During the drafting of article 27(2) of the Universal Declaration of Human Rights (UDHR) ${ }^{29}$ and article 15(1)(c) of the ICESCR, delegates already expressed their concern about including in human rights instruments the protection of interests in intellectual creations. Some delegates found the protection redundant with that offered by the right to private property and other rights in the instruments. Meanwhile, others considered such protection right only secondary to such fundamental human rights as prohibition on genocide, slavery, and torture; the right to life; or the right to freedom of thought, expression, association, and religion. Even today, commentators remain concerned that

\footnotetext{
$27 \quad$ Ibid para 2.

28 M. Sepúlveda, The Nature of the Obligations Under the International Covenant on Economic, Social and Cultural Rights (Antwerp, Intersentia 2003) 8.

29 Universal Declaration of Human Rights (n 10).
} 
the continuous proclamation of new human rights will undermine both the fundamental nature of human rights and the integrity of the process of recognizing those rights. ${ }^{30}$ Although these concerns are understandable, it may be too late to deny the protection of human rights-based interests in intellectual creations. In the UDHR, the ICESCR, and many other international or regional instruments, for example, the right to the protection of interests in intellectual creations is explicitly recognized as a human right. ${ }^{31}$

It may examine the three new challenges that may confront to the development of this framework, especially from the pro-development perspective: (1) the human rights ratchet of intellectual property protection, (2) the undesirable capture of the human rights forum by intellectual property rights holders, and (3) the framework's potential bias against non-western cultures and traditional communities. To be certain, there are additional challenges. From the standpoint of intellectual property rights holders, there is also a growing concern that the development of a human rights framework for intellectual property will undermine the balance of existing intellectual property systems. Just as public interest advocates are concerned about the upward ratchet of intellectual property rights through their association with human rights, rights holders are equally concerned about the downward ratchet of intellectual property rights, due to the fact that those attributes or forms of intellectual property rights that do not have human rights basis are likely to be deemed less important through a human rights lens. Notwithstanding this important concern, this paper focuses primarily on the prodevelopment concerns raised by the development of human rights framework for intellectual property. It seeks to explain why this framework will benefit not only individual authors and inventors, but also less developed countries and traditional communities.

\section{Impact of Intellectual Property Rights and the Realization of Human Rights}

Intellectual property rights as currently materialized in most legal system around the world are based on the premise that there must be a balance between the rights granted to the rights holder and society's interest in having access to novel development in the arts, science and technology ${ }^{32}$ The virtual isolation of intellectual property rights from broader debates concerning their impact on the realization of human rights or on environmental conservation has ended following the adoption of the TRIPS Agreement, whose main

30 P. Alston, 'Conjuring Up New Human Rights: A Proposal for Quality Control' (1984) 78 American Journal of International Law 607.

31 See, for example Additional Protocol to the American Convention on Human Rights in the Area of Economic, Social and Cultural Rights (opened for signature 17 November 1988) OASTS 9(1989), 28 ILM 161(Protocol of San Salvador) art 14(1)(c); ); International Covenant on Economic, Social and Cultural Rights (entered into force 3 January 1976) 999 UNTS 3 (ICESCR) art 15(1)(c); Organization of American States, American Declaration of the Rights and Duties of Man (2 May 1948) OEA/Ser. L./V./II.23 art 13; UDHR (n 3) art 27(2).

32 Philippe (n 2) 1. 
impact has been to substantially raise intellectual property rights standards in a majority of developing countries like Bangladesh ${ }^{33}$ In the context of a majority of developing countries and all least developing countries the implementation of the TRIPS Agreement has the potential to have significant impact on the realization of human rights. ${ }^{34}$ The link between intellectual property and the realization of human rights is not a new per se, but it has been made much more palpable after the adoption of the TRIPS agreement. Most of the developing countries have had and are having to quickly adopt intellectual property rights standards which have the potential to set off significant socio-economic disruption. This was probably never visible in developed countries, where the strengthening of intellectual property protection has largely been incremental.

The relationship between intellectual property rights and the realization of human rights in developing countries exist with regard to a number of human rights. They are easily observed in the case of the right to food and right to health. With regard to the human right to health, the relations have become apparent in the relationships between medical patents and the realization of the right to health, particularly in the context of the cancer HIV/AIDS epidemics. ${ }^{35}$ The real fact is that a number of drugs used to alleviate diseases like cancer and HIV/AIDS are protected by patent law. So there is a direct link to the price of drugs and access to the drugs. ${ }^{36}$ With regard to the food, there are also links between patents in the field of genetic engineering, the limitation of farmer's rights and access to food. ${ }^{37}$

The link between intellectual property rights and human rights has been established many times and the issue has been discussed extensively in human rights forums. There remains to date, a visible imbalance. So far, the language of human rights has not penetrated intellectual property rights institutions, while the language of intellectual property rights is now addressed in human rights institutions regularly ${ }^{38}$ At the UN level, this has been the case of Sub-Commission on the Promotion and Protection of Human Rights (SubCommission) and Economic Social and Cultural Rights Committee (ESCR)

The Sub-Commission particularly debated the question of the impact of intellectual property rights on the realization of human rights ${ }^{39}$.It indicated in a strongly worded statement:

\footnotetext{
33 Duncan Matthews, Globalizing intellectual property rights: The TRIPS agreement (2000).

34 See Aundrey R.Chapman, The Human rights implication of intellectual property protection (2002); See also United Nations Development program (UNDP), Human Development Report (2000).

35 Alicia Ely Yamin, 'Not Just a tragedy: Access to medications as a right under international law' 21(2) Boston University international law journal 325, 325-371; S. Joseph, 'Pharmaceutical Corporations and Access to Drugs: The Fourth Wave of Corporate Human Rights Scrutiny' (2003) ,25(2) Human Rights Quarterly 425, 425-452.

Philippe (n 2).

Ibid 414.

Ibid 25.

David Weissbrodt \& Kell Schoff (n 7).
} 
[T] hat since the implementation of the TRIPS Agreement does not adequately reflect the fundamental nature and indivisibility of all human rights, including the right of everyone to enjoy the benefits of scientific progress and its application, the right to health, the right to food, and the right to self -determination, there are apparent conflict between the intellectual property rights regime embodied in the TRIPS Agreement, on the hand and international human rights law on the other ${ }^{40}$

The Economic Social and Cultural Rights (ESCR) Committee has organized a day long general discussion on the issue in $2000^{41}$ following the public controversy concerning access to drugs, medical patents and rights to health in the context of the price of Cancer and HIV/AIDS drugs in developing countries which are mostly affected by the epidemics, ${ }^{42}$ The ESCR committee has further adopted a statement on intellectual property rights in 2001. In this statement, the ESCR committee argued that intellectual property protection must serve the objective of human well-being, which is primarily given legal expression through human rights ${ }^{43}$. It intimated that intellectual property regimes should promote and protect all human rights. ${ }^{44}$ The committee further provides that any intellectual property rights regime that would make it more difficult for a state to comply with its core obligations in relation to the right to health and food would be inconsistent with the legally binding obligations of the concerned state. ${ }^{45}$

Both the Sub-Commission and the ESCR committee in its 2001 Statement put the emphasis on the question of the impacts of the existing intellectual property rights on the realization of human rights. One of the specific concerns highlighted by the Sub-Commission was the fact that while the TRIPS Agreement identifies the need to balance the rights and interests of all concerned actors, it provides no guidance on how to achieve this balance. ${ }^{46}$

\section{TRIPS plus Measures and Human Rights}

'TRIPS plus' measures are norms which exceed the level of IPR protection required by the TRIPS Agreement. 'TRIPS plus is an informal term "which refers to efforts to extend patent life beyond the 20-year TRIPS minimum; limit compulsory licensing in ways not required by TRIPS; and limit exceptions which facilitate prompt introduction of generics. ${ }^{47}$

$40 \quad$ Intellectual Property Right and Human Rights ,CHR Res 2000/7.

41 Report on the Twenty Second, Twenty-Third and Twenty-Fourth Session, UN ESCOR Commission on Economics, Social and Cultural Rights (2000)

42 Philippe (n 2).

43 Report on the Twenty-Fifth, Twenty-Sixth and Twenty-Seventh Sessions: Statement by the Committee on Economic, Social and Cultural rights on human rights and Intellectual Property UN ESCOR 2001 (2001 Statement )

$44 \quad$ Ibid 25

45 ICESCR (n 31).

46 The Impact of the Agreement on Trade-Related Aspect Of Intellectual Property Rights On Human Rights, UN ESCOR (2001).

47 WHO, Globalization, TRIPS and access to pharmaceuticals: WHO Policy Perspectives on Medicines, No. 3 (March 2001) 4. 
'TRIPS plus' measures may also take the form of requirements to accede international patent treaties, such as Patent Cooperation Treaty, which provides an international procedure for filing patent applications, and the Patent Law Treaty, which harmonizes the administrative procedures for obtaining and maintaining patents.

TRIPS plus measure relates to the provision of exclusive rights over the data which is submitted to drug regulatory authorities. Drug regulatory system authorizes the marketing of pharmaceutical products, in order to ensure that they are of good quality, are safe and effective. The data that has to be provided to drug regulatory authorities (notably data of clinical and preclinical trials) differs from the information required for a patent application. Some jurisdictions mandate the provision of exclusive rights over those data, in order to prevent generic competitors from relying on those data. The resulting "data exclusivity" is likely to complicate and/or delay the marketing of generics - irrespective of patent protection.

TRIPS article 39(3) includes the following provision on data submitted to drug regulatory authorities:

Members, when requiring, as a condition of approving the marketing of pharmaceutical or of agricultural chemical products which utilize new chemical entities, the submission of undisclosed test or other data, the origination of which involves a considerable effort, shall protect such data against unfair commercial use. In addition, Members shall protect such data against disclosure, except where necessary to protect the public or unless steps are taken to ensure that the data are protected against unfair commercial use.

It has been argued that the requirement in article 39 (3) to protect data 'against unfair commercial use' amounts to data exclusivity. However, careful reading of the article does not warrant this conclusion; the WHO Commission on Intellectual Property Rights, Innovation and Public Health concluded that 'Article 39.3 ... does not create property rights, nor a right to prevent others from relying on the data for the marketing approval of the same product by a third party, or from using the data except where unfair (dishonest) commercial practices are involved. ${ }^{48}$

The human rights compatibility of data exclusivity and other TRIPS plus provisions depends on whether they advance the fulfilment of the right to health. The Special Reporter on the Right to the Highest Attainable Standard of Health has recommended that 'States be cautious about enacting 'TRIPS plus' legislation without first understanding the impact of such legislation on the protection of human rights, including the right to health.' Wealthy countries should not, according to the Special Reporter, "pressure a developing country to

48 Commission on Intellectual Property Rights, Innovation and Public Health. Public Health, Innovation and Intellectual Property Rights (WHO, 2006). 
implement 'TRIPS plus' legislation, unless reliable evidence confirms that such legislation will enhance enjoyment of the right to health in the developing country. ${ }^{49}$

There is a strong criticism against the TRIPS Agreement and TRIPS plus from both sides, namely those who wish to promote stronger protection of intellectual property, and those who consider that minimum standard set forth in the agreement is too high to allow developing countries to formulate policies for development. ${ }^{50}$ The former argue that the TRIPS Agreement does not necessarily provide for adequate and effective protection and support and promote the conclusion of bilateral free trade agreement including provisions which provide for the standards exceeding the minimum standard of the TRIPS Agreement .The latter argue that efforts by developing countries aimed at improving the balance from their perspective should be reflected in the review of the TRIPS Agreement and the following issues are of particular concern among developing countries. TRIPS and public health, transfer of technology and transitional arrangement. ${ }^{51}$

\section{Problems Arising from TRIPS in the Developing Countries}

The developing and least developing countries may move towards an era of debt economy where the patent holder can enforce its own condition for the use of invention and every other user would have to pay interest for the use of patent. This could well lead to a position where economy of the business houses of developing countries depends on the interest paid and could move towards debt economy.

There can be problems like starvation due to increase in food prices due to compliance to TRIPS Agreement because in the agricultural sector, the farmers would be burdened of paying royalties to the suppliers of improved variety of seeds since they would be the patient owners for such seed. One can well imagine the condition of general masses when according to United Nations Development Program (UNDP) half of world's population lives on less than $\$ 2$ a day; one- third has no access to electricity; a fifth has no access to clean drinking water and one in seven adults an in five children suffers from malnutrition.

TRIPS model of intellectual property is very much one of individual property rights freely assignable in the market place. Moral rights were not stressed. On this view, it would seem that TRIPS has a little to offer to secondary producers and to ensure even the independent local inventors, developed artists and performers who are not necessarily antagonistic to the notions of property rights.

\footnotetext{
49 Paul Hunt, Mission to WTO, Report of the Special Reporter on The right of everyone to the enjoyment of the highest attainable standard of physical and mental health E/CN.4/2004/49/Add.1 para.63, 81- 82.

50 See, for example, Constantine Michalopoulos, 'Special and Differential Treatment of Developing Countries in TRIPS' TRIPS Issue Papers 2, 4

$<$ http://www.quno.org/geneva/pdf/economic/Issues/Special-Differential-Treatment-in-TRIPS-

English.pdf $>$ accessed 1 March 2013.

51 Ibid.
} 
TRIPS is not directly concerned with the opportunity to sell products competitively, though one might imagine this concern was one of the rationale behind its provision. Rather it is designed to move the market from liberal and free economy towards monopolistic economy.

The agreement is markedly silent on the issue which has divided the United States and other industrial countries as to whether to recognize the first time intent or first to field. This difference complicates efforts to coordinate the processing of applications just at a time when more inventors are identifying a need to secure their markets across range of countries.

Drugs will become expensive and beyond the reach of common people due to heavy royalties being charged by the patent holder of such drug raising the drug prices. Many developing countries amend their patent laws to include products in pharmaceutical industry, industries in developing countries have to necessarily engage themselves in new product development to remain globally competitive. But Bangladesh has not amended its patent law till now and has not included pharmaceutical industry. Evidently very few of the companies would have the financial strength to undertake drug development as a part of their research and development portfolio.

TRIPS has made the term of protection of patent a minimum of 20 years (Article 33). This period has to be seen as an increase for many systems including those in the developed countries. At the same time, there is no provision for Utility Models. Utility models and their variants offer an alternative to inventors where it does not seem feasible to make the investment involved in securing the full patent.

Another impact is that invoking the provision of compulsory Licensing on the ground of non-availability of the patented invention to the public at reasonable prices would not be so easily possible in the present context. Mere allowance for compulsory licensing is of little help to the state today.

Another serious impact for every developing country is the added responsibility of saving its cultural and geographic identity from the clutches of developed countries and their business interest.

The author feels that there is hard time ahead for most of small scale industry in the third world country because of various problems like infrastructure, financial support and, of course, country's policy.

\section{Conclusion}

Intellectual property rights instruments have never directly addressed impacts on the realization of human rights. It needs to be reiterated that the TRIPS has achieved its goal ie, the modification of existing laws of member states to its minimum levels of protection. 
There is optimism that member states that deviate from the proper TRIPS minima will eventually comply, as the TRIPS dispute resolution mechanism as well as other national and international mechanism, have proven successful at coercing compliance even while developing countries could be hurt the most by TRIPS. It is hoped that developed countries will provide assistance to achieve in the end what everyone wants, a workable system of global trading. We are at a pivotal time for TRIPS when we will see whether TRIPS has achieved its purpose of bringing developing countries to a minimum level of intellectual property protection. It is also a pivotal time for the WTO generally, when we will see whether the TRIPS model of imposing 'positive' obligation on members is a viable approach to future WTO negotiation.

$* * * * * * * * * * * * * * * * * * *$ 